\title{
Workers vs Machines: Ottoman Tunis between Industrialisation and Colonisation
}

\author{
Nora Lafi
}

\begin{abstract}
The Ottoman province of Tunis between the 1850 s and its integration into the French colonial sphere in the 188 os, was marked by the emergence of new issues directly arising from an international configuration undergoing profound change. This chapter aims to analyse the relationship between economic development, geopolitics and local issues in the last decades during which the province belonged to the Empire. It will home in on an emblematic conflict, one related to the fate of workers and artisans in fez factories as they protested against what they saw as unfair competition imposed by the European powers, and against the industrialisation that followed the mechanisation of production. These new operating conditions, in a market subject to the growing dominance of foreign trade and to instability in local production, gave rise to many protests. This chapter endeavours to compare and contrast the different levels and scales of this sector, to explain the impact of a new global dimension on local balances and the vectors of a new form of foreign interference. These conflicts also involved different ways of negotiating the reformed relationship between the Ottoman Empire and its province of Tunis in the face of the threat of ever-increasing foreign domination and colonisation. Focusing on the voices of the most modest local players, who spoke out to condemn the deterioration of their living conditions, and on the local and international context, the chapter aims to reveal the dynamic interrelation between different levels and issues, and individual destinies and wider perspectives, at a time of great historical change.
\end{abstract}

\section{Introduction}

Between 1860 and 1877 , Tunis' urban society was stirred by a bitter dispute concerning not only foreign economic competition and the threat it posed to local production, but also the prospect that, in the capital of the Ottoman province, textile factories dedicated to manufacturing hats known as the fez (shashiyya or chechia) would be mechanised. Artisans and workers in the 
sector, threatened by this new development, protested repeatedly, addressing petitions to local authorities and the central government in Istanbul. The purpose of this chapter is to draw on these exceptional documents (the petitions themselves and the reports written in response to them) so as to interpret various issues related to the changing world of work in the context of great technological and economic change, and to the intermingling, at different levels, of local life and international realities. In Tunis, artisans and workers protested both against what they saw as the unfair competition imposed by the European powers and against the Ottoman response to this competition, which took the concrete form of a mechanisation perceived to be perverse and placed at the service of unbalanced development. They also protested against the tendency of local authorities to accept the new operating conditions of a market now dominated by foreign trade. The imposition of new conditions of production in Tunis was seen as a form of external control. This chapter will endeavour to compare and contrast the different levels and scales of this sector, in an attempt to explain not only the impact of a new global dimension on local balances, but also the vectors of a new form of foreign interference in a Tunis increasingly placed under tutelage. It also aims to decipher the different ways in which the reformed relationship existing between the Ottoman Empire and the province of Tunis was negotiated in the face of the threat of ever-increasing foreign domination and, before long, of colonisation. The development-related conflict analysed herein is read as an unfolding and deployment of broader issues that were the result not only of the economic development strategies adopted by the Ottoman Empire and the local elites of Tunis, but also of external interference exerting its influence far beyond the sphere of economic competition. A perspective 'from below' captures these issues in a way that brings out clearly the direct link between the living conditions of the population and major economic and geopolitical changes.

2

\section{Historiographical Considerations on the Impact of the Industrial Revolution on the World of Artisans in Different Contexts}

The publication in 1963 of E.P. Thompson's The Making of the English Working Class, a book destined to exert considerable influence, ensured that international historiography would begin to take a new look at the social consequences of the Industrial Revolution (Batzell et al., 2015). The shift from artisanal to industrial-type production began to be viewed not only in terms of economic rationality and efficiency, but also as an episode whose often traumatic social consequences needed to be studied. Thompson also stressed the need for a 
politicised reading of this transition, for which an analysis of the different phases of conflict can provide a crucial entry point.

The interpretation of the conflicts related to the advent and evolution of the various phases of economic transformation has since given rise to other important re-evaluations. For Europe, historians have shown that the roots of the Industrial Revolution went back to the various local forms of ancien régime and have stressed both the complexity of the processes of economic upswing and mechanisation (Verley, 1997) and the close link between the world of artisans and the industrial intensification of production (Guillerme, 1998 and 2007). This has led to a re-reading of mechanistic interpretations of the Industrial Revolution in which a simple technological innovation induced a paradigm shift affecting the whole economic system. Above all, we now know that the great nineteenth century economic transformation had actually started in the eighteenth century as an intensification of the artisanal economy of the ancien régime (Kaufhold, 1978; Cermann and Ogilvie, 1996). From arsenals to textile workshops, well before the invention of the steam engine, production had increased and the number of workers grown, fuelled by a large-scale rural exodus and sparking off rapid urbanisation. In many cities, there were real artisanal factories that employed thousands of working men and women whose work complemented that of thousands of female workers working from home. In other cities, the number of traditional shops and stalls had increased to such a degree that they changed the scale of neighbourhoods devoted to artisanal production. Hence, as recent historiography has taught us, we should move on from the outdated image of the history of artisanal production that portrays it as an activity confined to small-scale production activities. The mechanisation made possible by technical progress came to affect sectors that had not remained traditional, as might be suggested by our image of ancien régime artisans, since - in the eighteenth century already—-workshops in such sectors had become real factories. This was especially true for Britain, France, northern Italy and Flanders. In the United States too, the link between the intensive artisanal development of the late eighteenth century and the industrial upswing of the nineteenth century has been established by economic historians (Dawley, 1976; Stott, 1996).

When mechanisation impacted on these workshops, it was not only the masters and their apprentices who were affected; thousands of workers also experienced this change at first hand. As proto-industrialisation had benefited from a large labour force, industrialisation and the mechanisation it entailed came as an even bigger shock. It was in this context that workers' protests against mechanisation developed. Logically, it was Britain, where the replacement of the working masses by new tools occurred most rapidly, that was affected 
first - witness what is referred to as 'Luddism', a disparate movement that was nonetheless united in seeing machines as responsible for casting workers into poverty (Randall, 1986; Thomis, 1970; Winpenny, 1990).

For regions long regarded as peripheral, it is the whole relationship to $\mathrm{Eu}-$ rope that has recently been rethought in line with this questioning of the timing and the nature of the Industrial Revolution; a new critical approach to the study of the roots of domination and inequality in development has flourished. Taking into account the nuanced views developed by specialists in European economic history, and distancing themselves both from the topoi inherited from the colonial era (and even from the Enlightenment) and from those that paradoxically emerged from a critique of those former views, many historians of economic and social systems have emphasised the complexity of the phenomena of economic transformation. They have shown, for example, that the dissemination of technological changes resulting from the Industrial Revolution was not just a phenomenon that spread from North to South, losing intensity at every step due to the supposed lesser capacities of local societies to incorporate progress (Raveux and Sanchez, 2010). They have also shown that economic domination and colonisation were inextricably linked. In many cities too, from the Mediterranean to India, there had also been a phase of intensification of artisanal production in the eighteenth century. It is, of course, in the example of the Indian textile industry where historiography has made most progress in its analysis of the link between economic transition and the roots of colonial rule. In India, in fact, British colonial rule emerged in conjunction with the seizure of control over the textile sector, through predation on the markets and the clash with a competition affected by the transformation of the production system (Tirthankar, 2007). As far as Africa is concerned, recent historiography has also proposed new modes of analysis. For example, Bayart, with his concept of extraversion, is resolutely opposed to Hegelian stereotypes of an Africa rich in gold but still stuck in the early stages of exploiting its resources. Extraversion, for him, is typical of 'a systemic global economy that existed before the growth of the market and the capitalistic expansion of the West' (Bayart, 1999). Bayart disagrees with Rodney (1972) and Davidson (1969), according to whom it was changes in the European economy that led to the systems of historicity of countries that were thus relegated to the periphery. Instead, he proposes that we focus on African economies for what they were, and seek the dynamics of their evolution. He sees the formation of a rent of dependency as the historical matrix of inequality. This position is connected with the broader trend in recent historiography to adopt a critical attitude to judgments regarding what has been called 'modernism without modernity' that is to say, technical modernisation without social reform: something of 
which, it is claimed, only the so-called peripheries would have been capable (Guillén, 2004). It is also connected to a critique of the narrative of economic evolution in what was seen as the peripheries, following the challenging of those ideas defended by Landes in The Unbound Prometheus (Landes, 1969) on the dissemination of transformations in production techniques from England to Europe and the rest of the world.

It is now accepted that ontological and civilizational types of language can no longer be used as such to explain discrepancies in development (Bryant, 2006). In many cases, local dynamics pre-existed the intrusion of Europe and its technology, and this invites further reflection on the consequences of the penetration-imposition carried out by Europe and accompanied by a destabilisation of previously existing balances. Following the lead of Latin American historiography (see for example Dependencia y desarrollo en América Latina by Cardoso and Faletto, 1969), a whole new vein of similar ideas has been opened up.

An attempt must also be made to write a history of colonised and colonising societies that can take into account the multiple dimensions of the relation of dominance (Conklin, 2000; Mignolo, 2001). We should also embark not only on an exercise of 'provincialising Europe', as the salutary slogan suggested by Chakrabarty (2000) has it, but also on a discussion of all of the elements underlying the narrative and analysis of the history of the aforesaid peripheries, be they southern European, African, Ottoman, or more generally colonial.

For the Mediterranean, long considered in historiography as an indolent periphery of hard-working Europe, resistant to the industrial application of technological progress for reasons often reified in a static perception of local anthropology, it has been shown that the characters of proto-industrialisation were indeed present at the turn of the eighteenth and nineteenth centuries, in the Iberian peninsula (Chastagnaret, 2000), in Italy, and even in the Balkans and on the southern coastline of the Mediterranean. The question of why industrial development over the following decades and centuries was-as has been noted - so tardy has shifted: the focus now is especially on the structures of investment and the development of logics of domination.

For the Ottoman Empire during the second half of the nineteenth century, we must also move away from the interpretive framework of the simple dichotomy between the importing and exporting of solutions based on technical rationality, and from such general ideas as 'Westernisation' and 'Europeanisation'. The reflections of Hamadeh (2004) on this subject are illuminating, as they encourage a certain scepticism towards the interpretive trend based on a skewed view of what is seen as inevitable Ottoman decline. The interpretive framework has thus been extensively revised. In contrast to inherited views 
stemming from the 1950 and 1960 , themselves strongly marked by a powerful colonial and culturalist heritage, a vision of industrialisation has developed, in the Ottoman context, of its origins and its dead ends, that has advanced hand in hand with the progress in analytical methods in economic history that can be observed on several different fronts. The existence of the conditions for proto-industrialisation and of strong and dynamic trading networks has been demonstrated for the main cities of the Empire, from Istanbul to Trabzon and from Thessaloniki and Alexandria to Beirut or Crete. Ottoman receptivity to technological innovation has also been highlighted, and this has demonstrated the extent to which the Empire was integrated into international circuits of technical expertise. As for the crises experienced periodically in various sectors, they have been read in the light of the link between international relations and local conditions. Stress has also been laid on the variety of local configurations and dynamics. But the Ottoman case is specific in that it presents a situation that was deteriorating as a result of European competition that was not only economic, and gradually becoming more capitalistic, but also involved an element of interference in both diplomatic and military spheres, and often led to a violent occupation of the colonial kind. Development-related conflicts arising from industrialisation in the Ottoman Empire thus need to be interpreted in a specific light, combining the rapid economic, social and technological transformations that occurred with the pressures arising from an initially ambiguous relationship and then, clearly, from aggressive hostility. Quataert (1986) illustrates this intermingling of issues and levels with regard to Anatolia. Masters (1988), meanwhile, shows how early such ambiguities arose in the Ottoman Levant. For Egypt, the pioneering work of Fahmi (1954) demonstrates the depth of the transformation of the productive apparatus in Cairo in the eighteenth century and the extent of its social consequences in the nineteenth century-a mixture of intensification, mechanisation and crisis. From the work of Faroqhi and Hanna, we also now know that the milieu of Ottoman artisans had, during the eighteenth and early nineteenth centuries, experienced profound changes characterised by huge growth in production and manpower and an upheaval in the guild-based management structures inherited from the ancien régime (Faroqhi, 2009; Hanna, 2011). This was followed by a real slump in economic affairs of the Ottoman Empire, as a result of both the 'Great European Depression' of the 1880s and what had by then become an asymmetrical relationship (Pamuk, 1984). European competition, the Ottoman slump, and vectors of domination were thus linked. New goods and the paths via which they were traded were often imposed by foreign consular networks in the Ottoman provinces. Patronage networks were created, that partly incorporated the economy of the ancien régime, with the so-called capitulations of 
the Ottoman Empire, while changing its nature and intensity. The structures of the local artisanal system, structures that-far from being inert-had allowed an intensification of production in the late eighteenth century were destabilised. The textile sector crisis suffered by Tunis in the second half of the nineteenth century illustrates this logic and allows us to reflect on the links between economic change, foreign domination, and Ottoman imperial destiny.

The Crisis Experienced by Fez Manufacturers in Tunis:

A Development-Related Conflict and a Symptom of the Emergence of Colonial Issues

In Tunis during the second half of the nineteenth century, fez manufacturers, and sometimes even their workers, were repeatedly driven to protest—protests that took the form of petitions-against mechanisation, unfair competition from abroad, and the lack of protection for their products on export markets when those products were faced with the desire of other nations with ambitions to expand their own markets. The National Archives in Tunis house evidence of many such initiatives, and an analysis of these documents lies at the heart of this chapter. ${ }^{1}$ Such an analysis enables the historian to perceive not only the actors of the conflict, their interactions and their arguments, but also the way in which they negotiated and constructed a form of consensus through conflict. These archives also help one develop a kind of micro-history of transformations that are generally interpreted only via broad globalised narratives. In these archives (where conflicts also produce further archives ...), underlying development-related conflicts are noticeable. The occurrence of such conflicts reflects the way in which the Ottoman Empire tried to implement major economic reforms in what was then - since the loss of Algeria to French colonisation between 1830 and $185^{0}$ - its westernmost province, in tandem with the administrative reforms that it also promoted. In view of the involvement of foreign consulates and foreign chambers of commerce in the economic life of the province of Tunis, these conflicts also reflect the increasing influence of European powers in the Ottoman province, which in 1881 led to its military occupation and colonisation by France (Ganiage, 1959). The challenge for the entire economy of the Ottoman province of Tunis was, in fact, not only an economic modernisation linked to significant technical and capitalistic transformations, but also its relationship with the Empire and foreign domination.

1 ANT (Archives nationales de Tunisie), Series H (silsila al-tarikiyya: Historical Series), box 72, files 857 to 860 . 
The conflict that stirred the Tunisian textile sector in the 1860 os and 1870 s was indeed a development-related conflict: an entire sector revolted against the new conditions of production and integration into the international market, a major change by comparison to the previous economic situation in which the local economy had hitherto developed.

The fez had been produced in Tunis at least since the arrival of refugee artisans from Spain in the fifteenth century (Teyssier, 1962; Ferchiou, 1971; Bakalti, 1996; Ben Miled, 2010). Those refugees had fled the ethnic and religious cleansing campaigns undertaken during the different phases of the Christian reconquista as it swept through al-Andalus; they then settled in various cities of North Africa, including Tunis (Abidi, 2016). They benefited from the leniency of the various local authorities and created their guilds anew. Some historians, however, think that the fez originated in the city of Kairouan. From here, they claim, the tradition passed into Muslim Spain, and then back to Tunisia (Bachrouch, 2008). Integration into the Ottoman Empire-confirmed in 1574 but already largely effective, as regards trade, after the protection of the city against Christian attacks provided by the Ottoman corsair Barbarossa several decades earlier-comprised a favourable set of circumstances for the development of the textile industry, and particularly the production of fezzes. At the beginning of the Ottoman period, artisanal activity in Tunis was structured, to a significant extent, around this booming activity, bringing together the manpower of an entire region thanks to existence of then new outlets throughout the Ottoman world. Sheep rearing (fezzes are made of wool) also developed and provided additional prosperity to those living in the countryside. Much of the wool used was, however, still imported from Spain, as well as from Sicily and Sardinia. Urban infrastructure, including dyeing vats, was placed at the service of this sector. In Tunis, fez manufacturers were generally located in the medina, but also in the suburb of Ariana. During the sixteenth and seventeenth centuries, this activity came to represent a flagship economic sector for the Ottoman province. Each phase of production had a precise location either in town or in the surrounding area (Bachrouch, 2008). Boubaker shows that the export of fezzes to the entirety of the Ottoman Empire constituted the main manufactured item exported through the port of Tunis (Boubaker, 2003). The cities of the Levant, from Damascus to Aleppo and from Jerusalem to Beirut, were reliable markets. But the same was also true of cities such as Smyrna or Salonica. The Ottoman army was also a major customer. Fezzes were also often bought and worn throughout Mediterranean Europe, as evidenced by numerous Sardinian and Sicilian engravings and descriptions. The fez was, in short, the main example of the Imperial Ottoman dimension of ancien régime trade and a certain globalisation of artisanal production throughout 
the Mediterranean. The term 'artisanal', however, should not mislead us as to the scale and nature of production activities that, even before mechanisation, was highly intensive. It has been calculated that around 5,000 workers were employed in fez factories in the medina of Tunis and adjacent suburbs in the late eighteenth century (Spring and Hudson, 2004). The French travellers Peyssonnel and Desfontaines estimate that between 15,000 and 20,000 people were employed as manual workers, artisans, or apprentices in 1724 (Peyssonnel and Desfontaines, 1838; Bachrouch, 2008). Production in 1760 is estimated to have been 660,000 units per year, double what it was in 1740 (Boubaker, 2003). With the monopoly Tunis enjoyed in the Empire, the margins on sales of this product were, for the trading companies of Tunis, quite comfortable. Youssef Sahib al-Tabaa, active in the eighteenth century and influential in the spectacular growth of the sector at that time, is emblematic of the fortunes made by Tunisian merchants engaged in the fez trade throughout the Ottoman Empire.

The milieu of the fez manufacturers was very hierarchical, from the workers and apprentices to the big merchants. But with industrial and proto-industrial development, the pyramid of skills and symbolic hierarchies changed. A growing number of workers filled the increasingly large workshops. Along with olive oil producers, fez manufacturers (the term as used here refers to the owners of these workshops and the organisers of this trade) thus formed a well-off class that had emerged from a guild that had not originally been one of the most noble, but that was well established in the urban environment and local society, and had connections throughout the Empire (Hadi Cherif, 1970). The elite of these fez producers was made up of some 300 masters (Tunger-Zanetti, 1996).

But with the arrival of mechanisation, and new competition from Europe and other Ottoman cities engaged in an effort to modernise, the whole of the Tunis textile industry faced a major test that challenged not only the production system, but also the existence of commercial opportunities and the entire social system that depended on them, causing a significant drop in living standards for the working men and women concerned. The two phenomena were related but different: new competition emerged as new players entered the market, and as certain Tunis entrepreneurs tried to respond by mechanising their activity they came into conflict with the traditional hierarchy of the guild. But the crisis had actually begun well before mechanisation took place. So it was, first, a crisis brought about by new and aggressive competitors breaking into a traditionally exclusive market. From the 1780 s onwards, trading companies in Orléans, Lyon and Marseille managed to force the whole of the Ottoman Empire to accept the textile production of their respective regions, through a mixture of commercial dynamism, (pre-)industrial espionage and 
diplomatic pressure exerted on the Empire. ${ }^{2}$ From this time onwards, European consuls brought pressure to bear on local authorities and the Empire, resorting to threats of military action if necessary, to force them to agree to revise the terms of former trade agreements. The intensification of artisanal production in Europe, which foreshadowed the Industrial Revolution, also created unprecedented differences in cost prices. Even the fez sector, which had seemed to possess a cultural specificity that placed it beyond the reach of competition from another continent, was affected by this transformation (Valensi, 1969). To penetrate the Ottoman market, a veritable system of technological espionage was set up through the consular network, at a time when consuls were still generally merchants: dyes, weaving and crushing processes, trading posts, customs provisions, and transport arrangements: all were targeted for close observation by the new competitors in order to create similar products and ensure market penetration. Diplomatic efforts, requested by chambers of commerce, ensured that permission was obtained to import products into the Empire, if necessary by exerting a pressure that foreshadowed the more active interventions of the coming century. And European expansion into Tunisia, and the Ottoman Empire in general, was not unconnected to the transformations then taking place in the European textile and artisanal sector (and before long in the industrial sector too). The entire way the province of Tunis was positioned in the Ottoman market, and its relationship to the Empire, were thus rapidly undermined. This phenomenon was further complicated by the appearance of native Ottoman competition due to the development (desired by various reformers) of a fez industry in Cairo from 1825 onwards (Fahmi, 1954) and in Istanbul from 1827. Muhammad Ali's government brought in experts from the fez-makers' guild of Tunis to create a new production structure locally in Cairo. In the 1830s, fez-manufacturing workshops in Cairo employed more than 2,00o workers. The sale of fezzes, initially confined to the Egyptian army, was opened up to the general public and the export market in 1834 (Fahmi, 1954). This development symbolised Muhammad Ali's wish to see Egypt enter a phase of economic transition that would lead it towards industrialisation (Thieck, 1992). In Istanbul, to deal with the order placed by the Ottoman army for more than 50,00o fezzes, Tunisian master hosiers were asked to set up manufacturing structures (Tunger-Zanetti, 1996). These initially mimicked the guild-based structure found in Tunis, but then moved towards a less rigid, industrial-type method of organisation. The figure of 'Umar al-'Abrî, a dealer

2 See Archives of the Chambre de Commerce de Marseille, CCC, LIII, 360: Correspondants à l'étranger: Barbarie. 
in fezzes who was close to the government in both Istanbul and Tunis, embodied this transfer between 1829 and the 1860 s. His networks in the imperial capital and the way he drew upon them to further his business interests naturally led to arguments with the artisans of Tunis (Tunger-Zanetti, 1996). The conflicts discussed below also stemmed in part from a rivalry between, on the one hand, people from Tunis living both there and in Istanbul, who were keen on industrial modernisation (these included 'Umar al-'Abrî and Yahyâ Arway, who were close to the reformer Khayr al-Dîn), and, on the other, the profession's guild base.

Thus, in the mid-nineteenth century, the position of Tunis exporters had already become difficult due to the shrinking of the Ottoman market and the advent of European competition-but also because of emerging tensions in Tunis itself. The artisanal sector in general was facing an almost existential crisis (Penec, 1964). And it was here where the first popular Maghrebi opposition to mechanisation occurred. Even if we cannot quite use the term 'Luddism', as the archives for Tunis do not directly record any acts of sabotage targeting the machines being introduced into the artisanal sector as it transformed into an industry, the rhetoric of protest against the replacement of the labour force by machines was clearly in evidence. First and foremost, the various players in the industry resorted to petitions in an attempt to express their grievances both to the provincial authorities and to those in Istanbul. In the Ottoman administrative system of the ancien régime, the petition lay at the heart of the processes of mediation and of consensus building during phases of conflict (Lafi, 2012). ${ }^{3}$ It also lay at the core of decision-making procedures: any petition entailed, both in Istanbul and in the province concerned, the opening of an official file, and the response to each petition involved an investigation, interviews, and a rescript - that is to say, the formalisation of the decision taken (Lafi, 2011). A summary of each petition was placed by the administration at the beginning of the file. Local chronicles-true civic annals-recorded the submission of petitions and provide evidence of their existence and kind. ${ }^{4}$ For fez makers, the submission of these numerous petitions points to a shared economic, social, civic and political awareness of the group as an urban and professional milieu faced by the economic adversity occasioned both by foreign competitors and by Ottoman modernisers close to the Tunisian local government. These petitions are evidence of a collective mobilisation that aimed not only

3 It also needs to be said that, in terms of mentality, this feature largely survived the modernising reforms of the era of the Tanzimat (Reforms), which - between the 1830 os and the 1870 , and throughout the whole Empire-promoted a new bureaucratic rationality.

4 See the accounts in Bayram al-Khâmis (2000) and Ben Diaf (2004). 
to draw attention to a particular problem, but also to force the political system to respond and recreate the conditions necessary for a local consensus. They also reflected the way in which — at every level—local, imperial and geopolitical issues were interrelated.

The Ottomans and the Tunisian local government-in an effort to develop the province and the Empire and to ward off the new competition-decided, in the late 1850 os, to mechanise the manufacture of fezzes. To do so, they called on various foreign experts, who offered to supply steam engines. The Ottomans also modernised the infrastructural framework by building dams to improve the supply of water to fez factories. The souks themselves were modernised in a similar way. All this took place in the context of the Tunisian province following the enactment of the Fundamental Pact in 1857, and the negotiations between the government, reforming ministers and foreign consuls that led, in 1861, to the adoption of the constitution. Khayr al-Dîn played a decisive role in this movement (Van Krieken, 1976). The negotiations were largely concerned with determining the extent to which foreigners would be allowed to wield economic influence over the province. Reformers such as Khayr al-Dîn were proponents of economic modernisation aiming for industrial development that alone could free the province from foreign domination; they were also, in this modernisation process, the ambiguous partners of consuls, bankers and foreign investors. The rejection of mechanisation by the guild base, whose organisation was itself challenged by the reforms, was therefore both a rejection of the reformers (and the imperial and local Tunis-based economic circles close to them) and a rejection of foreign influence, already perceived as a vehicle for domination, in the economy. The guild base had already, in support of its leadership, mobilised en masse a few decades earlier to prevent fezzes produced in Europe being sold in the Tunis souk: 'In the past, Christians introduced fezzes they had produced at home. They were forbidden to approach the Tunis souk as it would harm our industry' (Bachrouch, 2008, 80o). Several petitions submitted at the time had led to the banning of these imports and protected Tunisian production throughout the Empire. In 1860, in a context that had itself evolved due to the opening of the Tunisian market to foreigners following the Fundamental Pact and its various accompanying measures, protests against the import of European fezzes resumed, led by Hassûna al-Wazîr, the amin (representative of the guild) of fez traders and producers: 'Today we are seeing them launch a new offensive. If this goes on, we will completely lose our profession' (Bachrouch, 2008, 802-803). The petition was ignored by the authorities. Hassûna al-Wazîr was not allowed to present his case to the ministry. None of the negotiating procedures normally instigated in response to a 
petition was opened. The following year, faced with the worsening of the sector's economic situation, and also with the prospect of modernisation leading to increasing mechanisation-modernisation supported by the authorities themselves-the case took a new turn.

The main petition considered here was part of this context in which the leaders of the profession, and its base, mobilised against the local government of the province and against the entrepreneurs who, in their view, were siding with both modernisers and foreigners. ${ }^{5}$ The petition resides in an archive file that includes several petitions regarding the sector. ${ }^{6}$ It was probably addressed to the prime minister of the local Tunisian government (Sayyidnâ al-wazir alakbar Adam Allah) in $1861 .{ }^{7}$ It was signed by 77 individuals who describe themselves, in the text, as members of the guild ( $\operatorname{arba\hat {b}} a$-sinâ $\hat{a}^{\prime}$ ) and as poor workers in the fez manufacturing sector (min al-fuqarẩ al-mushtaghalîn bi sinâa alshâshiyya). The main demand of the petitioners was that measures be taken to ban the import of machinery for the manufacture of fezzes. For them, these machines were literally killing thousands of fez makers in Tunis (al-hâdira) and the rest of the country (al-watan). They pointed out-and this indicates how grave the crisis really was-that the situation no longer allowed the children of the capital and of the nation, men (zukûr), women (anâth), widows (arâmal) and even orphans (aytâm), all working day and night (yachtaghilûna bihâ bil-layl wa al-nahâr), to survive. The use of these strong words, which connoted a koranic religious ethic that protected widows and orphans - an ethic to which sura 4 (al-Nisa) of the Koran gives the most powerful expression, indicated a desire to force the administration addressed by the petition to face up to its social and moral responsibility:

If our Sayyid allows the import of machinery by foreigners (ajânib), he will be causing the abandonment (ihmâl al-ahâli) of all those people who have only their craft skills and their hands to work with, and of all those who depend on this work [...] We weak people (nahnu al-du'afầ), through our voices and by submitting this petition (bi saddad bathth alchikâyya), remind our Sayyid that his duty is to protect us and ensure that he does not open doors that will never close again.

5 ANT, Series H, box 72, file 859, document 6 .

6 ANT, Series $\mathrm{H}$, box 72 , files 857 to 860 .

7 The document bears no date. Its date can be deduced from a reading of the context and the other documents in the same file. 
The petition is written in the urban dialect typical of Tunis at the time, substantially different from the one we find in petitions submitted by notables from the civic councils, who were more familiar with this exercise (Lafi, 2005). These notables wrote in classical Arabic and deployed a finely honed administrative and legal rhetoric. Artisans and workers could quote the Koran in moral support of their demands, but they were obviously less familiar with the imperial style of communication embodied by the petition. Still, they were proficient in the essentials. Their insistence that they were ordinary working people could even be seen as a deliberate choice made to reinforce the impact of their petition. The petition does not directly include any large-scale economic argument: the emphasis is solely on the social consequences, at the local level, of decisions over which the petitioners have no control. The archive file shows that, before addressing the highest authorities, they had gone through the whole gamut of protest and mediation within the guild hierarchy, itself in the process of being reformed. But in the face of a stalemate, the artisans and workers exercised their right of petition to address the higher authorities directly. They were expressing the distress of a social group united in adversity. Because of their decision to focus on social issues, some of the main issues were not addressed in the petition: international competition, import taxes, measures to support artisans, general points about the industrialisation of the province. But in other petitions, and investigative files of the local and imperial administration, these themes were sometimes addressed. Some petitions protested directly against mechanisation. ${ }^{8}$ Others were submitted by trades that represented the different phases of fez production, such as pressing. ${ }^{9}$ In fact, in those years - the 1860s-the whole artisanal sector was affected by this manner of threat and by the economic slump it induced, as illustrated by protests in the leather and dyeing sectors (Amîn al-dabâgha wa mâ yata 'allaq bil-sinâa $a$ ), whose petitions are to be found next to those of the fez producers in the archives. ${ }^{10}$ Throughout the 186os, this type of agitation left its mark on the Tunisian social landscape and on the political debate concerning the opening up of the economy; this was when Khayr al-Dîn and the reformers were attempting to modernise the province, attempts that were riddled with ambiguity. The influence of European penetration was also starting to be perceptible: this involved competition and exemptions, and undermined Tunis' market

8 ANT, Series H, box 72, file 860 .

$9 \quad$ ANT, Series $\mathrm{H}$, box 72 , file 857,19 petitions and documents.

10 ANT, Series H, box 59, file 658 (dyeing). Box 59, file 659 (tanners). See also Sebag (1959). 
share and the local and imperial responses to this new context. The reform of guilds, in the Empire in general and in Tunis in particular, was part and parcel of such reactions. ${ }^{11}$ It triggered a number of political and institutional debates that lasted for several years (Quéméneur, 1942; Louis, 1973).

These episodes show that the European influence in the Ottoman province of Tunis was fundamentally ambiguous from the outset and that Ottoman efforts to bring about economic modernisation were already trammelled by an increasingly colonial situation. Faced with the industrialisation of Europe, the Ottoman Empire tried, in various contexts including that of fez production, to promote a transition to a mechanised, industrial-type economy. But during this transformation, which included multiple development-related conflicts over several decades, several elements merely intensified ambiguities and a growing dependency: the importation of technology, investment mechanisms, the redefinition of marketing channels, relationships with foreigners, and changes in social relations at the local level. Regarding this last dimension, the shock of the disappearance of guilds as such was a powerful blow in the Ottoman context of the Tanzimat and their local variations in Tunis, from modernising economic reforms to the destabilising effects on the cohesion of the social milieu of production. These facts, if interpreted in the context of reflections on the overall history of development-related conflicts discussed here, suggest that we go along with the suggestions of Kenneth Pomeranz (2000) on the high degree of pre-industrial productive development in certain areas, including - in this case-Ottoman Tunis, which historiography has tended to consider right from the outset as peripheral. But we should also see these suggestions as an invitation to compare and contrast different levels, from the local and social micro-level to the geopolitical level, to understand the mechanisms that led to the gradual surrender to what was becoming a colonial order: the pressure to open up markets, the ambiguities of mechanisation, and the debates in local societies regarding how modernisation should proceed and the role of the state. In the context of Ottoman Tunis, the affirmation of modernity as a hegemonic paradigm was thus enacted through a seizing of power of the mechanisms of economic decision-making by circles situated outside the guild heritage, and resulted in an abrupt transition, the increasingly colonial nature of which only served to increase its gravity. The social body of

11 See ANT, Series H, box 59, files 644-669, on the end of the corporations in the medina (dyers, tanners, potters, burnous makers, butchers, blacksmiths, etc.). Here too, the petition turned out to be a fundamental vector of mediation. 
the former productive milieus was dismantled in the process-as the petition studied here demonstrates.

With French colonisation, which was formalised in Tunisia in 1881 after two decades of progressive losses of Ottoman imperial sovereignty, a paradoxical swing occurred: it was now the colonial authorities who were responsible for defending Tunisian artisanal production on the international market. While, for several decades, it had been partly against the French that Tunis had had to defend its production and marketing conditions, French colonial administrators were now asked to intervene with regard to the issues affecting the sector-requests submitted in the form of petitions, from 1882 onwards. This is the context in which, twenty years later, the archive file on which the research for this chapter has drawn was created: a French colonial official apparently asked, at the beginning of the twentieth century, for a file to be opened so that the issue could be studied, and we see, here and there, his comments added in pencil to the original documents. Papers dating back several decades were collected, taken out of their original archival context and compiled in a newly opened file.

From the mid-188os, the situation continued to worsen for Tunis fez manufacturers. German and Austrian competitors entered the market, challenging the position of the Tunis manufacturers even more severely, and the situation became completely untenable. In 1895, Le Jacquard, a French journal of the wool industry, waged a negative campaign aimed — this time - at protecting Tunisia (now a French colony) from European competition, indicating that Austrian fezzes were available in Tunis for 'even less than the cost of the actual amount of wool needed to make a fez [...] Germany and Austria have managed to monopolise the exclusive sale of this item of clothing' (Le Jacquard, 1895, 345 , our transl.). Tunisia was pushed right out of the international market. Fez production in Tunisia reverted to an artisanal stage that it had already outgrown back in the eighteenth and nineteenth centuries, and became almost irrelevant. Despite efforts by the Tunisian nationalists of the 1940s and 1950s, followers of Habib Bourguiba, to assert that the wearing of the fez was a form of cultural distinction and a political sign of support for independence, production continued to decline. Cultural debates about the symbolism of the fez between the Tunisia of Destour and the Turkey of M. Kemal Atatürk (Doğaner, 2009), regardless of how the hat itself developed, did not alter the economic reality of the sector and the social situation of those who had dedicated their skills and labour to it. Over the following decades, the fez gradually became 
less central to the culture of Tunis, and was finally confined to the folklore of the souks in the context of tourist development. In terms of economic history, it became the symbol of a failed attempt to boost artisanal production in the industrial age.

\section{References}

Abidi, B. (2016) Refugees from Al-Andalus and the Urban Evolution of the Lower Medjerda Valley, paper presented at the Urban Studies Seminar, ZMO, Berlin, 7 March.

Bachrouch, T. (2008) La médina de Tunis avant le Protectorat, Cahier de CERES, Série Histoire, 17 (Tunis: CERES).

Bakalti, S. (1996) La femme tunisienne au temps de la colonisation (Paris: Harmattan).

Batzell, R., S. Beckert, A. Gordon and G. Winant (2015) 'Writing Social History 50 years after the Making of the English Working Class', Journal of Social History, 48(4), pp. 753-758, DOI: 10.1093/jsh/shvo36.

Bayart, J.-F. (1999) 'L'Afrique dans le monde: une histoire d'extraversion', Critique Internationale, 5, pp. 97-120, DOI: 10.3406/criti.1999.1505.

Bayram al-Khâmis, M. (2000) 'Safwa al-i'tiba', 5 vol., (Tunis: Ministry of Culture).

Ben Diaf, A. (2004) 'Ithâf al-zamân bi-akhbâr mulûk tûnis wa 'ahd al-amân, Dâr al-', 5 vol. (Tunis: arabiyya lil-kitâb).

Ben Miled, M. (2010) Chéchia: le bonnet de feutre méditerranéen (Carthage: Editions Carthaginoiseries).

Boubaker, S. (2003) 'Négoce et enrichissement individuel à Tunis du XVIIe siècle au début duXIXesiècle',Revue d'histoire moderne et contemporaine, $50(4), 29-62$, https:// www.cairn.info/revue-d-histoire-moderne-et-contemporaine-2003-4-page-29.htm (accessed on 26 May 2016).

Bryant, J. (2006) 'The West and the Rest Revisited: Debating Capitalist Origins, European Colonialism and the Advent of Modernity', Canadian Journal of Sociology, 31(4), pp. 403-444.

Cardoso, F.H. and E. Faletto (1969) Dependencia y Desarrollo en América Latina (Buenos Aires: Siglo Veintiuno).

Cermann, M. and S. Ogilvie (1996) European Proto-industrialization (Cambridge: Cambridge University Press).

Chakrabarty, D. (2000) Provincializing Europe. Postcolonial Thought and Historical Difference (Princeton: Princeton University Press).

Chastagnaret, G. (2000) L'Espagne, une puissance minière au XIXème siècle (Madrid: Casa de Velazquez).

Conklin, A. (2000) 'Boundaries Unbound: Teaching French History as Colonial History and Colonial History as French History', French Historical Studies, 23(2), DOI: 10.1215/00161071-23-2-215. 
Davidson, B. (1969) The African Genius: an Introduction to African Cultural and Social History (Boston: Little Brown and Company).

Dawley, A. (1976) Class and Community: the Industrial Revolution in Lynn (Cambridge: Harvard University Press).

Doğaner, Y. (2009) 'The Law on Headdress and Regulation on Dressing in the Turkish Modernization', Bilig, 51, pp. 65-86, http://bilig.yesevi.edu.tr/yonetim/kcfinder/upload/files/bilig-51-guz-2009.pdf (accessed on 26 May 2016).

Fahmi, M. (1954) La révolution de l'industrie en Egypte et ses conséquences sociales au XIXème siècle (1800-1850) (Leiden: Brill).

Faroqhi, S. (2009) Artisans of Empire. Crafts and Craftspeople under the Ottomans (London: Tauris).

Ferchiou, S. (1971) Technique et société: l'exemple de la fabrication des chéchias en Tunisie (Paris: Institut d'ethnologie).

Ganiage, J. (1959) Les origines du Protectorat français en Tunisie (1861-1881) (Paris: PUF).

Guillén, M. (2004) 'Modernism without Modernity? The Rise of Modernist Architecture in Mexico, Brazil and Argentina, 1890-1940', Latin American Research Review, 39(2), DOI: 10.1353/lar.2004.0032.

Guillerme, A. (2007) La naissance de l'industrie à Paris: entre sueurs et vapeurs (1780-1830) (Seyssel: Champ Vallon).

Guillerme, A. (1998) Révolution artisanale, révolution industrielle: la technique face aux métiers (Paris: CNAM).

Hadi Chérif, M. (1970) 'Expansion européenne et difficultés tunisiennes de 1815 à 1830', Revue de l'Occident musulman et de la Méditerranée, 8, 111-114, DOI: 10.3406/ remmm.1970.1035.

Hamadeh, S. (2004) 'Ottoman Expressions of Early Modernity and the "Inevitable" Question of Westernization', The Journal of the Society of Architectural Historians, 63(1), pp. 32-51, DOI: 10.2307/4127991.

Hanna, N. (2011) Artisan Entrepreneurs in Cairo and Early Modern Capitalism (Syracuse: Syracuse University Press).

Kaufhold, K.H. (1978) Das Gewerbe in Preussen um 1800 (Berlin: Schwartz).

Lafi, N. (2012) 'La gouvernance ottomane des équilibres locaux: le rôle du bureau central des pétitions et l'usage de ses archives', Cahiers du Ceres, 21, pp. 261-274.

Lafi, N. (2011) 'Petitions and Accomodating Urban Change in the Ottoman Empire', in E. Özdalga, S. Özervarlı and F. Tansuğ. (eds.) Istanbul as seen from a distance. Centre and Provinces in the Ottoman Empire (Istanbul: Swedish Research Institute), pp. $73-82$.

Lafi, N. (2005) 'Les pouvoirs urbains à Tunis à la fin de l'époque ottomane: la persistance de l'ancien régime', in N. Lafi (ed.) Municipalités méditerranéennes (Berlin: K. Schwarz), pp. 223-244. 
Landes, D. (1969) The Unbound Prometheus: Technological Change and Industrial Development in Western Europe from 1750 to the Present (Cambridge: Cambridge University Press).

Le Jacquard (1895) Le Journal de l'industrie lainière (Paris: H. Saint-Denis).

Louis, A. (1973) 'Les industries du cuir à Tunis hier et aujourd'hui: éléments bibliographiques', Revue de l'occident musulman et de la Méditerranée, 15, pp. 145-151, http://www.persee.fr/doc/remmm_0035-1474_1973_num_15_1_1234 (accessed on 26 May 2016).

Masters, B. (1988) The Origins of Western Economic Dominance in the Middle East. Mercantilism and the Islamic Economy in Aleppo, 1600-1750 (New York, London: New York University Press).

Mignolo, W. (2001) 'Coloniality at Large. The Western Hemisphere in the Colonial Horizon of Modernity', The New Centennial Review, 1(2), pp. 19-54.

Pamuk, S. (1984) 'The Ottoman Empire and the Great Depression of 1873-1896', The Journal of Economic History, 44(1), pp. 107-118, DOI: 10.1017/So022050700031399.

Penec, P. (1964) Les transformations des corps de métiers de Tunis sous l'influence d'une économie externe de type capitaliste (Tunis: ISEAAN).

Peyssonnel, A. and R.L. Desfontaines (1838) Voyage dans les Régences de Tunis et d'Alger (Paris: Gide), http://catalogue.bnf.fr/ark:/12148/cb3033070of (accessed on 26 May 2016).

Pomeranz, K. (2000) The Great Divergence: China, Europe, and the Making of the Modern World Economy (Princeton: Princeton University Press).

Quataert, D. (1986) 'Machine Breaking and the Changing Carpet Industry of Western Anatolia, 1860-19o8', Journal of Social History, 19(3), pp. 473-489, DOI: 10.1353/ jsh/19.3.473.

Quéméneur, J. (1942), 'Contribution à l'étude des corporations tunisiennes: Les Belghajia de Tunis', IBLA, 5 , pp. 26-51.

Randall, A. (1986) 'The Philosophy of Luddism: The Case of the West of England Woolen Workers, ca. 1790-1809', Technology and Culture, 27(1), pp. 1-17.

Raveux, O. and A. Sanchez (2010) 'La adaptación tecnológica como factor de localización industrial. Una revisión de las investigaciones sobre la industria de hilados de algodón en Cataluña (1772-1885)', Investigaciones de Historia Economica, 17(6), pp. $65^{-94}$.

Rodney, W. (1972) How Europe underdeveloped Africa (London: Bogle-L'Ouverture Publications).

Sebag, P. (1959) 'L'industrialisation de la Tunisie: une expérience dans l'industrie de la chaussure', Cahiers de Tunisie, 7, pp. 147-173.

Spring, C. and J. Hudson (2004) 'Urban Textile Traditions of Tunisia', African Arts, 37(3), pp. 24-41, DOI: 10.1162/afar.2004·37·3.24. 
Stott, R. (1996) 'Artisans and Capitalist Development', Journal of the Early Republic, 16(2), pp. 257-271.

Teyssier, P. (1962) 'Le vocabulaire d'origine espagnole dans l'industrie tunisienne de la chéchia', Mélanges offerts à Marcel Bataillon, Bordeaux, 1962, pp. 732-740.

Thieck, J.-P. (1992) Passion d'Orient (Paris: Karthala).

Thomis, M. (1970) The Luddites: Machine-Breaking in Regency England (Hamden: Archon Books).

Thompson, E.P. (1963) The Making of the English Working Class (London: Victor Gollancz).

Tirthankar, R. (2007) 'Out of Tradition: Master Artisans and Economic Change in Colonial India', The Journal of Asian Studies, 66(4), pp. 963-991, DOI: 10.1017/ Soo2191180700126X.

Tunger-Zanetti, A. (1996) La communication entre Tunis et Istanbul 1860-1913: Province et métropole (Paris: L'Harmattan).

Valensi, L. (1969) 'Islam et capitalisme: production et commerce des chéchias en Tunisie et en France aux XVIIIe et XIXe siècles', Revue d'histoire moderne et contemporaine, $16(3)$, pp. 376-400.

Van Krieken, G.S. (1976) Khayr al-Dîn et la Tunisie (1850-1881) (Leiden: Brill).

Verley, P. (1997) L'échelle du monde. Essai sur l'industrialisation de l'Occident (Paris: Gallimard).

Winpenny, T.R. (1990) Bending Is Not Breaking: Adaptation and Persistence Among 19th Century Lancaster Artisans (Lanham: University Press of America). 